\title{
OPTIMISATION OF PARAMETERS FOR THE PRODUCTION OF PERFORATED ARMOUR PANELS MADE OF NANOBAINITIC STEEL USING DYNAMIC HARDNESS MEASUREMENT METHODOLOGY
}

\author{
OPTYMALIZACJA PARAMETRÓW WYTWARZANIA BLACH PANCERNYCH \\ PERFOROWANYCH ZE STALI NANOBAINITYCZNEJ \\ Z WYKORZYSTANIEM METODYKI POMIARU DYNAMICZNEJ TWARDOŚCI
}

\begin{abstract}
The study is a continuation of the development of material characteristics in order to expand the range of products for the production of which nanostructured bainitic steels can be used. The tests included measurement of dynamic properties important in the material qualification process for firing tests and for other applications requiring dynamic wear resistance. The novelty of the implemented development of the innovative grade of nanostructured steel and the technology of manufacturing products - including armour systems containing perforated panels made of this grade of steel, consisted in developing the basics of dynamic hardness measurement methods and dynamic indentation tests using a Gleeble simulator.
\end{abstract}

Keywords: nanobainitic steel, dynamic hardness, perforated panels, ballistic resistance
W pracy kontynuowano opracowywanie charakterystyk materiałowych w celu poszerzenia asortymentu wyrobów, do woytwarzania których można zastosować stale nanostrukturalne bainityczne. Badania obejmowaty pomiary wtaściwości dynamicznych istotnych w procesie kwalifikacji materiatu do testów ostrzatem oraz do innych zastosowan wymagajacych odporności na zużycie dynamiczne. Nowość realizowanego rozwoju innowacyjnego gatunku stali nanostrukturalnej oraz technologii wytwarzania wyrobów - w tym systemów opancerzenia zawierajacych blachy perforowane z tego gatunku stali, polegata na opracowaniu podstaw metody pomiaru twardości dynamicznej oraz testórw wegtębiania dynamicznego z zastosowaniem symulatora Gleeble.

Stowa kluczore: stal nanobainityczna, twardość dynamiczna, blachy perforowane, odporność balistyczna

\section{INTRODUCTION}

The optimisation of production technology for nanostructured bainitic (nanobainitic) steel products for application in armour components, especially in the scope of chemical composition and final heat treatment parameters, is still a current research and development issue in many scientific and industrial centres [1-7]. The study, the results of which are contained in this paper, is a continuation of the development of material characteristics in order to expand the range of products for the production of which nanobainitic steels can be used [8-10]. The subject of the study includ-

Corresponding Author: jaroslaw.marcisz@imz.pl ed issues related to the measurement of dynamic properties important in the material qualification process for firing tests and for other applications requiring dynamic wear resistance. The novelty of the planned scope of research and measurement consisted in the development of the innovative grade of nanostructured steel and the technology of manufacturing products - including armour systems containing perforated sheets made of this grade of steel, and in developing the basics of dynamic hardness measurement methods and dynamic indentation tests using a Gleeble simulator. Designing puncture-resistant systems containing perforated steel plates requires analysis and proper selection of two main factors: mechanical properties of the panels and the perforation system, which will also ensure proper protection and significant weight reduction in relation to a solid 
plate. The protective effect of the perforated panel is largely based on the "edge effect"that occurs when the projectile core hits a specific zone around a hole. Perforation systems are designed with the assumption of the maximum probability of an "edge effect". The distance between adjacent openings should ensure that there is no phenomenon of "punching" of the fragments of the panel. As a result, there is an optimal solution that meets the mentioned protective requirements and ensures significant weight reduction.

Currently, there is no standardised method for measuring dynamic hardness, but research is being carried out to use the penetrator indentation method at high speed to assess the properties of armour materials, including using the Hopkinson bar method [11] or other methods [12, 13]. According to the commonly used definition of hardness of metals and alloys, this is the resistance measured by the stress exhibited by the tested material in the process of indenting an indenter made of a harder material, as a result of which a permanent indentation forms. Indirect measurement methods are also used, using the relationship between hardness and Young's modulus - scleroscopic or reflection methods (e.g. Leeb or Shore) that will not be analysed. The most commonly used standardised methods for measuring metal hardness are the Vickers, Brinell and Rockwell methods. In the case of the Vickers and Brinell methods, the hardness is expressed as the ratio of the applied load to the surface area of the impression, in $\mathrm{kG} / \mathrm{mm}^{2}$ units. In the Rockwell $\mathrm{C}$ method, the measure of hardness is the depth of the impression after applying a $150 \mathrm{~kg}$ load - a change in hardness by 1 HRC corresponds to a change in depth by $2 \mu \mathrm{m}$ [14]. The PN-EN ISO 14577-1:2015-09 standard [15] defines three ranges of hardness measurement by indentation:

- macro range, characterised by indenter load in the range from $2 \mathrm{~N}$ to $30 \mathrm{kN}$,

- micro range characterised by indenter load below $2 \mathrm{~N}$ and imprint depth above $0.2 \mu \mathrm{m}$,

- nano range characterised by an imprint depth $\leq 0.2 \mu \mathrm{m}$.

The standards do not directly specify the indenter rate for measuring macrohardness, but the indentation rate has been indirectly limited as follows [16, 17]: the time from the beginning of the application of the force until reaching the full load in the test may not be shorter than $2 \mathrm{~s}$ or longer than $8 \mathrm{~s}$. Thus, in the case of static hardness measurement, if the imprint depth is, for example, $100 \mu \mathrm{m}$ (which for the Rockwell C method corresponds to 50 HRC), the indenter's rate should be between $5 \cdot 10^{-3} \mathrm{~m} / \mathrm{s}$ and $1.25 \cdot 10^{-3} \mathrm{~m} / \mathrm{s}$.

If the indenter rate increases above the limit value for measuring static hardness, i.e. above approx. $10^{-3} \mathrm{~m} / \mathrm{s}$, the measure of material resistance in the indentation process is called dynamic hardness.

Based on many studies on empirical relationships between static hardness $H_{\mathrm{S}}$ and stress at plastic strain during uniaxial stretching of metals, the following relationship was established [18, 19]:

$$
H_{\mathrm{S}}=c \sigma_{\mathrm{f}}
$$

where $c$ is a constant, and $\sigma_{\mathrm{f}}$ is the stress in the uniaxial stretching test with a plastic strain of "f". For the Vickers hardness measurement method (1), it assumes the following form:

$$
H V_{\mathrm{S}}[\mathrm{MPa}] \approx 3 \sigma_{\mathrm{y}(\text { at } 8 \% \text { strain })}[\mathrm{MPa}]
$$

where $\sigma_{\mathrm{y}}$ is the stress in a uniaxial stretching test at a permanent plastic deformation of $8 \%$.
A comprehensive quantitative description and interpretation of phenomena occurring during the dynamic impact of the indenter on the material was first developed by D. Tabor [20] for an indenter in the form of a ball falling freely on the tested material at a relatively low terminal velocity, up to approx. $1 \mathrm{~m} / \mathrm{s}$. Based on his own experience and measurement results of other researchers, Tabor determined that for the applied measurement parameters, i.e. low velocity and mass of the penetrator, dynamic hardness $H_{\mathrm{D}}$ is expressed by the relationship:

$$
H_{\mathrm{D}}[\mathrm{MPa}]=\frac{\text { penetrator energy }}{\text { permanent indentation volume }}
$$

As a result of many studies, it has been established that dynamic hardness $H_{\mathrm{D}}$ increases in relation to static hardness $H_{\mathrm{S}}$ with increasing penetrator rate, or - in general - with increasing strain rate in the penetrator indentation area, in accordance with the approximate empirical exponential relation given below [19]:

$$
H_{\mathrm{D}}=H_{\mathrm{S}}\left[1+\left(\frac{\dot{\varepsilon}}{\dot{\varepsilon}_{\mathrm{r}}}\right)^{\mathrm{n}}\right]
$$

where

$\dot{\varepsilon}$ - the strain rate,

$n$ - the material constant - hardening coefficient,

$\dot{\varepsilon}_{\mathrm{r}}$ - the material constant with the value for metals and alloys in the range $10^{4}-10^{6} \mathrm{~s}^{-1}$.

\section{Dependence of dynamic hardness on the strain rate caused by the indenter}

Assuming the examples of solid material values for steel [19]: $\dot{\varepsilon}_{\mathrm{r}}=1.25 \cdot 10^{6} \mathrm{~s}^{-1}$ and $n=0.2$, the dynamic hardness increase coefficient in the following dependence (4):

$$
k_{\mathrm{D}}=\left[1+\left(\frac{\dot{\varepsilon}}{\dot{\varepsilon}_{\mathrm{r}}}\right)^{\mathrm{n}}\right]
$$

assumes the values given in Table 1 for increasing strain rates.

Table 1. Calculated values of coefficient $k_{\mathrm{D}}(5)$, for a strain rate within the range of $1-10^{6} \mathrm{~s}^{-1}$

Tabela 1. Obliczone wartości współczynnika $k_{\mathrm{D}}(5)$, dla prędkości odkształcenia w zakresie $1-10^{6} \mathrm{~s}^{-1}$

\begin{tabular}{|c|c|c|c|c|c|c|c|}
\hline$\dot{\varepsilon}\left[\mathrm{s}^{-1}\right]$ & $10^{0}$ & $10^{1}$ & $10^{2}$ & $10^{3}$ & $10^{4}$ & $10^{5}$ & $10^{6}$ \\
\hline $\boldsymbol{k}_{\mathbf{D}}$ & 1.06 & 1.10 & 1.15 & 1.24 & 1.38 & 1.60 & 1.96 \\
\hline
\end{tabular}

The estimated calculations presented in Table 1 show that dynamic hardness begins to increase significantly compared to static hardness, when the strain velocity takes the value of $10^{2}-10^{3} \mathrm{~s}^{-1}$, reaching about twice the value of static hardness for the strain velocity of $10^{6} \mathrm{~s}^{-1}$. The exponential functional relationship (4) describes the increase in dynamic hardness in an approximate way. Based on experimental data, it was determined that the actual course of the dependency of $H_{\mathrm{D}}$ from $\dot{\varepsilon}$ for metals and alloys can be divided into two ranges - up to a value of strain rate equal to approx. $10^{3} \mathrm{~s}^{-1}$, there is a slight increase in line with the relationship close to linear, and above the strain rate of approx. $10^{3} \mathrm{~s}^{-1}$, the increase in dynamic hardness is very fast [19]. It can be concluded that the different rate of hardness increase in the two mentioned ranges of strain rate results from different mechanisms of strengthening of the tested material in these strain rate ranges. Based on the observation of changes in the microstructure of metals and alloys (including high-strength steels) occurring as a result of high strain rates, it can be hypothesised that the effect of a sudden increase in dynamic hardness after exceeding a certain value of strain rate (of $10^{3} \mathrm{~s}^{-1}$ ) is associated with the onset of the formation of zones 
with a localised large accumulation of strain energy, which includes adiabatic shear bands. This hypothesis is confirmed by e.g. research on the impact of high strain rate on the microstructure of alloy steels, which shows that adiabatic shear bands were observed after exceeding a strain rate of $3 \cdot 10^{3} \mathrm{~s}^{-1}$ [21].

\section{MATERIAL, SCOPE AND METHODOLOGY}

The material for the study consisted of sections of nanobainitic steel sheets with the chemical composition given in Table 2. The test samples were subjected to heat treatment including the following stages: austenitising at $950^{\circ} \mathrm{C}$ for 30 minutes, cooling in air and direct annealing at isothermal transformation temperature. The following temperatures: 210,215 and $225^{\circ} \mathrm{C}$, and times of 120,96 and 72 hours respectively were applied.

In addition, tests were carried out on material after annealing at $690^{\circ} \mathrm{C}$ for 4 hours. Table 3 presents the mechanical properties of the material determined in a static tensile test.

The methodology of the dynamic indentation test using a Gleeble simulator was developed in the study. In the first stage of research, measurement parameters were developed regarding the range of indenter rate, indenter shape and hardness determination methodology. Subsequently, indentation tests were carried out in the optimal velocity range and for various variants of heat treatment of nanostructured steel. The physical interpretation of the obtained results and the comparison with standard parameters characterising the mechanical properties of steel was no less important than the selection of the parameters for taking measurement according to the new method.

Technological issues regarding the possibility of plastic forming (e.g. bending) and/or punching (for perforation) were undertaken. The tests included measurement of hardness and bendability of steel in the temperature range $650-100^{\circ} \mathrm{C}$, which was achieved by cooling from an austenitising temperature of $950^{\circ} \mathrm{C}$. The tests concerned the structural state of steel in the form of undercooled austenite and were referred to a material that has undergone a softening treatment as standard.

The thematic scope related to ballistic resistance testing of perforated panels included the selection of a variant of heat treatment of panels that would most likely obtain the highest penetration resistance for the tested material and the selection of the appropriate perforation system for the indicated variant and panel thickness. As a result of a comprehensive analysis of the properties, panels with an optimal perforation scheme and parameters of the final heat treatment were made for the construction of the armour system. The perforation was obtained with laser cutting. The experimental armour system was subjected to firing tests.
Table 3. Results of mechanical properties measurement in a static tensile test

Tabela 3. Wyniki pomiarów właściwości mechanicznych w statycznej próbie rozciągania

\begin{tabular}{|c|c|c|c|c|c|}
\hline $\begin{array}{c}\text { Variant } \\
\text { designation }\end{array}$ & $\begin{array}{c}\boldsymbol{R}_{\text {po.2 }} \\
{[\mathbf{M P a}]}\end{array}$ & $\begin{array}{c}\boldsymbol{R}_{\mathrm{m}} \\
{[\mathbf{M P a}]}\end{array}$ & $\begin{array}{c}\boldsymbol{A}_{\mathbf{5}} \\
{[\%]}\end{array}$ & $\begin{array}{c}\boldsymbol{A}_{\mathrm{gt}} \\
{[\%]}\end{array}$ & $\boldsymbol{R}_{\mathrm{m}} / \boldsymbol{R}_{\mathbf{0 . 2}}$ \\
\hline \multirow{4}{*}{ P1.210.120 } & 1525 & 2076 & 12.8 & 7.36 & 1.36 \\
\cline { 2 - 6 } & 1489 & 2067 & 14.4 & 9.83 & 1.39 \\
\cline { 2 - 6 } & 1510 & 2062 & 15.2 & 9.60 & 1.37 \\
\hline \multirow{4}{*}{ P1.215.96 } & 1531 & 2050 & 8.8 & 9.44 & 1.34 \\
\cline { 2 - 6 } & 1536 & 2048 & 12.6 & 8.72 & 1.33 \\
\cline { 2 - 6 } & 1453 & 2047 & 9.8 & 8.63 & 1.41 \\
\hline \multirow{3}{*}{ P2.215.96 } & 1575 & 1974 & 14.0 & 8.96 & 1.25 \\
\cline { 2 - 6 } & 1355 & 1966 & 13.2 & 7.53 & 1.45 \\
\cline { 2 - 6 } & 1477 & 1961 & 14.2 & 8.57 & 1.33 \\
\cline { 2 - 6 } & 1316 & 1972 & 14.0 & 9.84 & 1.50 \\
\cline { 2 - 6 } & 1317 & 1987 & 15.4 & 10.3 & 1.51 \\
\hline
\end{tabular}

\section{TEST RESULTS AND SUMMARY}

\subsection{RESULTS OF INDENTER PENETRATION EXPERIMENTS WITH A GLEEBLE 3800 SIMULATOR}

Fig. 1 presents examples of the relationship between the force value and the indenter displacement recorded during dynamic penetration experiments. In the experiments, an imprint depth of 1.8-2.1 mm was obtained for a constant velocity of $1 \mathrm{~m} / \mathrm{s}$ and an assumed setpoint value of penetration depth of $1.5 \mathrm{~mm}$. Due to the inertia of the measuring system and the different characteristics of material strain hardening, no repeatability of the imprint depth was obtained. The maximum force during the tests was $33-34 \mathrm{kN}$ for the softened material and 35 to $41 \mathrm{kN}$ for the material after final heat treatment.

The ratio of force (maximum force) to the lateral surface area of the indentation area (HDG) was determined as a measure of the effect of dynamic indentation in experiments carried out using Gleeble - analogously to the HB and $\mathrm{HV}$ hardness. It was roughly assumed that the measurement resulted in a cone-shaped crater, and therefore the lateral surface area of this figure was assumed to be $\pi r l$. For the softened material, the indentation resistance was from 242 to $258 \mathrm{kG} / \mathrm{mm}^{2}$. The remaining samples after the final heat treatment were characterised by a depth of indentation in the range of $350-368 \mathrm{kG} / \mathrm{mm}^{2}$ (Table 4). The direction of the HDG resistance value changes depending on the condition of the material being tested, and roughly corresponds to the direction of the HV10 hardness changes.

\subsection{MEASUREMENT OF HARDNESS FOR NANOBAINITIC STEEL IN THE SCOPE OF METASTABLE AUSTENITE USING THE POLDI METHOD}

The Poldi method was used to determine the hardness of the material in the temperature range of $100-650^{\circ} \mathrm{C}$ in the undercooled austenite phase, which was austenitised at

Table 2. Chemical composition of the test material, weight \%

Tabela 2. Skład chemiczny materiału do badań, \% masowe

\begin{tabular}{|c|c|c|c|c|c|c|c|c|c|c|c|}
\hline Material label & C & Mn & Si & P & S & Cr & Mo & AlT & Cu & N, ppm & O, ppm \\
\hline P1 & 0.59 & 1.69 & 1.60 & 0.012 & 0.004 & 1.40 & 0.59 & 0.022 & 0.07 & 24 & 7 \\
\hline P2 & 0.56 & 1.82 & 1.74 & 0.017 & 0.004 & 1.47 & 0.75 & 0.025 & 0.09 & 28 & 11 \\
\hline
\end{tabular}


a)

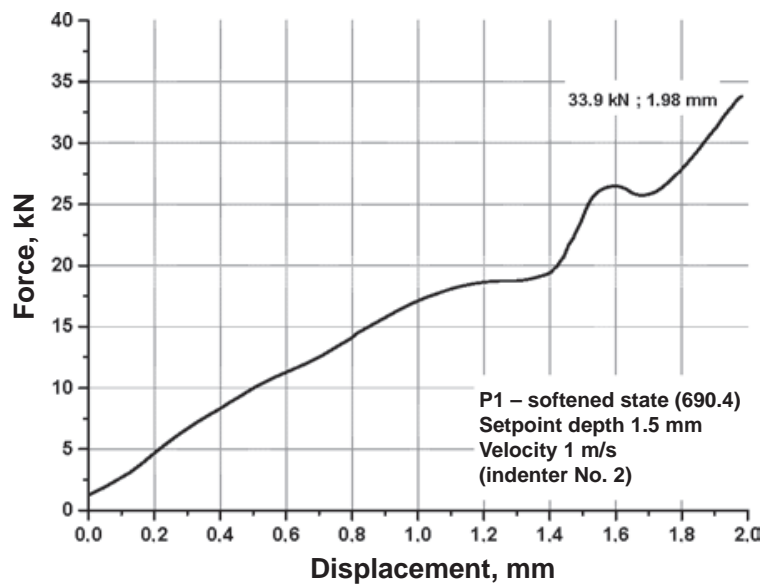

b)

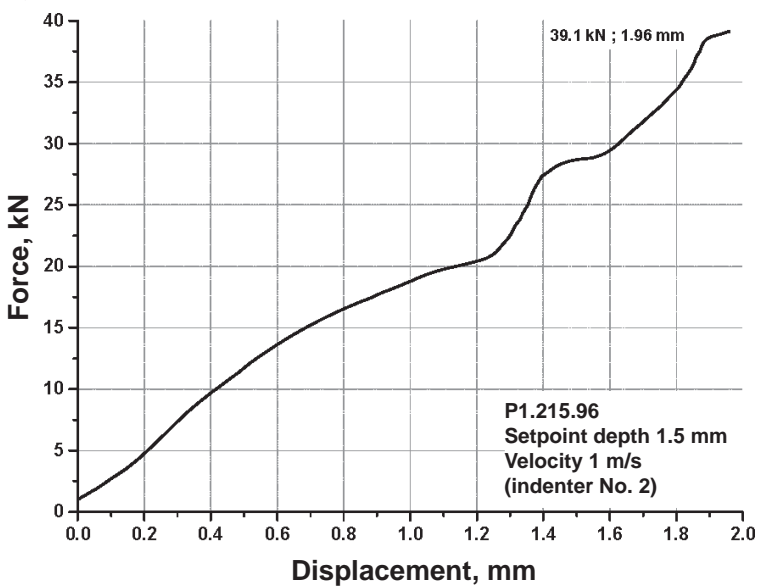

Fig. 1. Changes in force as a function of penetrator displacement. P1 nanobainitic steel; a) after annealing $690^{\circ} \mathrm{C} / 4$ hours, b) after final heat treatment $215^{\circ} \mathrm{C} / 96$ hours

Rys. 1. Zmiany siły w funkcji przemieszczenia penetratora. Stal nanobainityczna $\mathrm{P1}$; a) stan po wyżarzaniu zmiękezającym $690^{\circ} \mathrm{C} / 4$ godziny, b) stan po finalnej obróbce cieplnej $215^{\circ} \mathrm{C} / 96$ godzin

Table 4. Results of measurement of force, displacement and diameter of the imprint, as well as calculations of the dynamic indentation resistance HDG. Measurement using a Gleeble simulator at a tool velocity of $1 \mathrm{~m} / \mathrm{s}$. The table presents the results of the measurement of the HV10 hardness

Tabela 4. Wyniki pomiarów siły, przemieszczenia i średnicy odcisku oraz obliczeń oporu dynamicznego wgłębiania HDG. Pomiary za pomocą symulatora Gleeble przy prędkości narzędzia $1 \mathrm{~m} / \mathrm{s}$. W tabeli przedstawiono wyniki pomiarów twardości HV10

\begin{tabular}{|c|c|c|c|c|c|c|c|c|}
\hline $\begin{array}{c}\text { Sample } \\
\text { identification }\end{array}$ & $\begin{array}{c}\text { Fmax, } \\
{[\mathrm{kN}]}\end{array}$ & $\begin{array}{c}\text { Fmax } \\
{[k G]}\end{array}$ & $\begin{array}{c}h \\
{[\mathrm{~mm}]}\end{array}$ & $\begin{array}{c}d \\
{[\mathrm{~mm}]}\end{array}$ & $\begin{array}{c}r \\
{[\mathrm{~mm}]}\end{array}$ & $\begin{array}{c}l \\
{[\mathrm{~mm}]}\end{array}$ & $\begin{array}{c}\text { HDG } \\
{\left[\mathrm{kG} / \mathrm{mm}^{2}\right]}\end{array}$ & HV10 \\
\hline \multirow{2}{*}{ P1.690_4 } & 32.9 & 3354.88 & 2.10 & 3.30 & 1.650 & 2.671 & 242 & 304 \\
\hline & 33.9 & 3456.85 & 1.98 & 3.31 & 1.655 & 2.581 & 258 & 302 \\
\hline \multirow{2}{*}{ P1.210.120 } & 38.9 & 3966.71 & 1.82 & 2.99 & 1.495 & 2.355 & 359 & 622 \\
\hline & 39.9 & 4068.68 & 1.83 & 3.03 & 1.515 & 2.376 & 360 & 622 \\
\hline \multirow{2}{*}{ P1.215.96 } & 35.5 & 3620.01 & 1.96 & 2.73 & 1.365 & 2.388 & 354 & 615 \\
\hline & 39.1 & 3987.11 & 1.96 & 2.94 & 1.470 & 2.450 & 353 & 617 \\
\hline \multirow{2}{*}{ P1.225.72 } & 41.3 & 4211.44 & 1.88 & 3.02 & 1.510 & 2.411 & 368 & - \\
\hline & 40.4 & 4119.67 & 1.86 & 3.10 & 1.550 & 2.421 & 350 & 615 \\
\hline \multirow{2}{*}{ P2.215.96 } & 38.5 & 3925.92 & 1.95 & 2.93 & 1.465 & 2.439 & 350 & 613 \\
\hline & 39.5 & 4027.89 & 1.85 & 3.05 & 1.525 & 2.398 & 351 & 612 \\
\hline
\end{tabular}

$h$ - penetrator displacement (elastic and plastic strain),

$d$ and $r$ - diameter and radius of the base of the cone, respectively - trace of the imprint on the surface of the sample,

$l$ - the cone's slant height.

$950^{\circ} \mathrm{C}$ and controlled cooling to the measurement temperature immediately prior to the measurement. The second variant was a material in a softened state (annealed), which was heated from ambient temperature to the temperature of hardness measurement. The purpose of this measurement was to determine the hardness of undercooled austenite and compare it with the hardness of the softening annealed material. The development of the characteristics of nanobainitic steel in the undercooled austenite state is important from the point of view of sheet production technology, e.g. at the cutting immediately after hot rolling and/or bending in further processing. The results of this measurement can also be used in the design process of perforation technology using punching.

The tests used $9.2 \times 20 \times 150 \mathrm{~mm}$ steel samples $\mathrm{P} 1$ in the softened state, ground on both sides, with a thermocouple with a diameter of $2 \mathrm{~mm}$ mounted mid-thickness.

The hardness measurement was carried out for the following structural states of the material:

- In the softened state (after annealing) at ambient temperature - reference variant
- hardness measurement in the softened state at ambient temperature using the Poldi method

- In the softened state (after annealing) at increased temperature

- heating the sample with a thermocouple to $500^{\circ} \mathrm{C}$

- continuous recording and reading of the sample temperature using a thermocouple

- hardness measurement using the Poldi method (HPT) after reaching the following temperature: $400^{\circ} \mathrm{C}$, $350^{\circ} \mathrm{C}, 300^{\circ} \mathrm{C}, 250^{\circ} \mathrm{C}, 200^{\circ} \mathrm{C}$

- immediately after the last measurement, reheating the sample to $400^{\circ} \mathrm{C}$, after temperature equalisation without annealing - another HPT hardness measurement cycle on the other side of the sample, according to the same model.

Hardness measurement immediately after cooling from the austenite range:

- heating the sample with a thermocouple to $950^{\circ} \mathrm{C}$ and holding for 30 minutes

- hardness measurement using the Poldi method (HPT) after reaching the following sample temperature: $600^{\circ} \mathrm{C}$, 


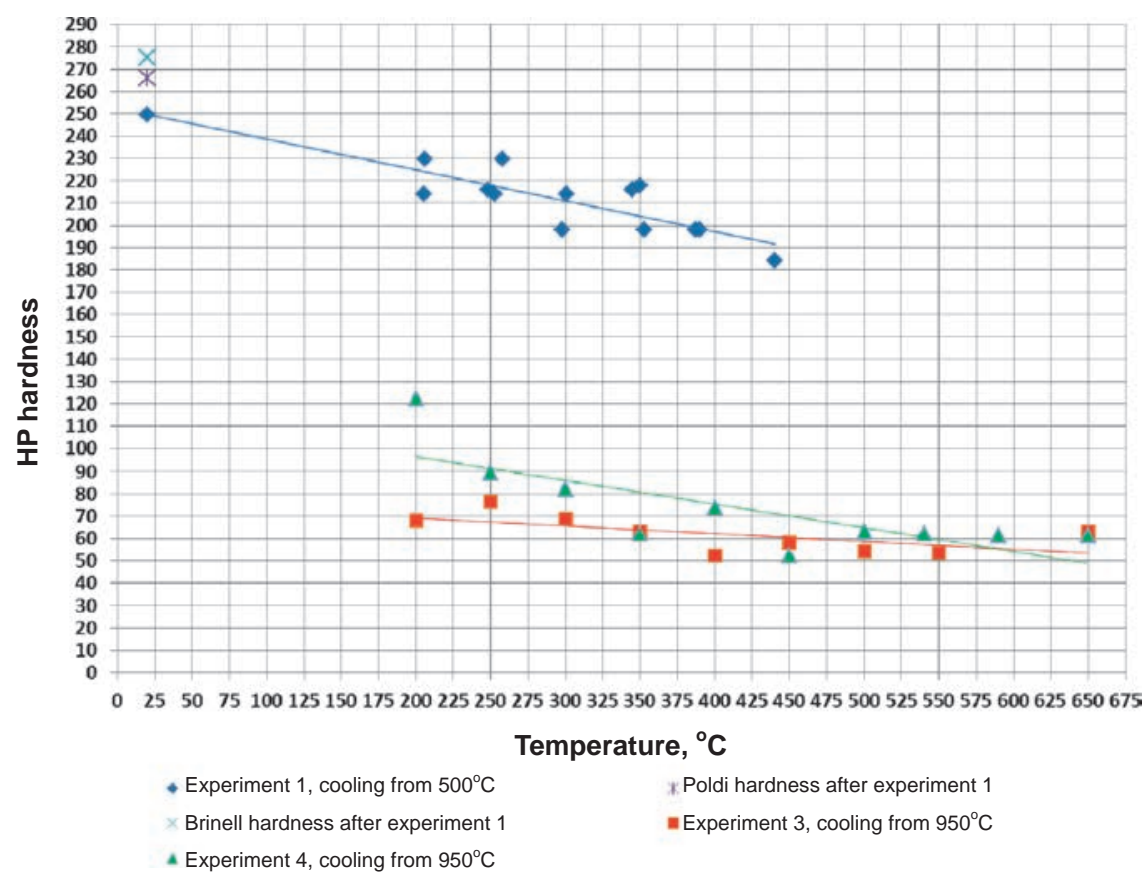

Fig. 2. Hardness of the P1 nanobainitic steel within temperature range up to $650^{\circ} \mathrm{C}$

Rys. 2. Twardość stali nanobainitycznej P1w zakresie temperatury do $650^{\circ} \mathrm{C}$

$550^{\circ} \mathrm{C}, 500^{\circ} \mathrm{C}, 450^{\circ} \mathrm{C}, 400^{\circ} \mathrm{C}, 350^{\circ} \mathrm{C}, 300^{\circ} \mathrm{C}, 250^{\circ} \mathrm{C}$, $200^{\circ} \mathrm{C}, 150^{\circ} \mathrm{C}$ and $100^{\circ} \mathrm{C}$

- immediately after the last measurement, reheating the sample to $850^{\circ} \mathrm{C}$, after temperature equalisation - without annealing - another HPT hardness measurement cycle on the other side of the sample, according to the same scheme.

The hardness measurement using the Poldi method was carried out for the softened material, which was heated to the test temperature in the range of $450-200^{\circ} \mathrm{C}$. A hardness of 180-230 HP was obtained for temperatures of 400 and $200^{\circ} \mathrm{C}$, respectively. An armco iron grade plate with a hardness of approx. $80 \mathrm{HBW}$ was prepared for the measurement of the hardness of nanobainitic steel in the undercooled austenite state. The material has a very low hardness of approx. 60 to $90 \mathrm{HP}$ in the temperature range $650-250^{\circ} \mathrm{C}$. After reaching the temperature of $200^{\circ} \mathrm{C}$, hardness increases due to the initiation of martensitic transformation. Due to the above, it was not possible to measure hardness at 150 and $100^{\circ} \mathrm{C}$ due to too large differences in the diameter of the imprint between the tested and the related plate.

Fig. 2 contains a summary of the results of hardness measurements for nanobainitic steel in the temperature range up to $650^{\circ} \mathrm{C}$ for the state of softened material heated to the test temperature and for the subcooled condition of austenite. The measurement results show that the hardness of undercooled austenite at the temperature range of $200-650^{\circ} \mathrm{C}$ is very low and much lower than the material softened by annealing. This enables shaping and punching of the material in this state of microstructure and temperature range, with much lower process energy and tool wear, and with good deformability, including resistance to cracking.

\subsection{BENDING TESTS OF METASTABLE AUSTENITE}

The static bending experiments were performed on a Zwick250 universal testing machine. $9 \times 20 \times 150 \mathrm{~mm}$ samples made of the P1 material in the softened state and with a punch diameter of $10 \mathrm{~mm}$ and a distance between sup- ports of $100 \mathrm{~mm}$ were used. During the test, the bending force and total mid-point deflection were recorded. The first experiment was carried out at ambient temperature and concerned the softened material. Further bending tests were carried out at temperatures around 300,430 and $450^{\circ} \mathrm{C}$, after prior austenitising of the samples at $950^{\circ} \mathrm{C}$ and controlled cooling to the test temperature. The aim of the measurement was to determine the bending stress and assess the bendability of the material.

The bending stress $R_{\mathrm{p} / \mathrm{zg}}$ initiating the plastic deformation of the sample was determined from the following relationship:

$$
R_{\mathrm{p} / \mathrm{zg}}=\frac{F_{\mathrm{z} / \mathrm{g}} L}{4 W}
$$

where

$F_{z / g}$ - bending force for reaching plastic deformation [N]

$L$ - distance between the supports $[\mathrm{mm}], W=\frac{b h^{2}}{6}$

$b$ - sample width [mm]

$h$ - sample height [mm].

Fig. 3a shows the results of the measurement of bending force and displacement for the material in the softened state at ambient temperature. The bending force at the point initiating plastic strain, equal to $15.25 \mathrm{kN}$ was determined, and bending stress $R_{\mathrm{p} / \mathrm{zg}}$ corresponding to this force was $1350 \mathrm{MPa}$. For the material in the state of austenite undercooled from $950^{\circ} \mathrm{C}$, the following test temperatures were used: 450,430 and approx. $300^{\circ} \mathrm{C}$. The temperature was determined on the basis of measurement with an optical pyrometer and it concerned the sample surface. The measurement results showed very low values of bending force of 2.5 and $4.0 \mathrm{kN}$ and corresponding bending stresses $R_{\mathrm{p} / \mathrm{zg}}$ of 221 and $354 \mathrm{MPa}$ for the test temperature of $430-450$ and $300^{\circ} \mathrm{C}$ respectively (Fig. $3 \mathrm{~b}$ ). The test results confirmed the very high deformability of nanobainitic steel in the undercooled austenite at $300-450^{\circ} \mathrm{C}$. 
a)

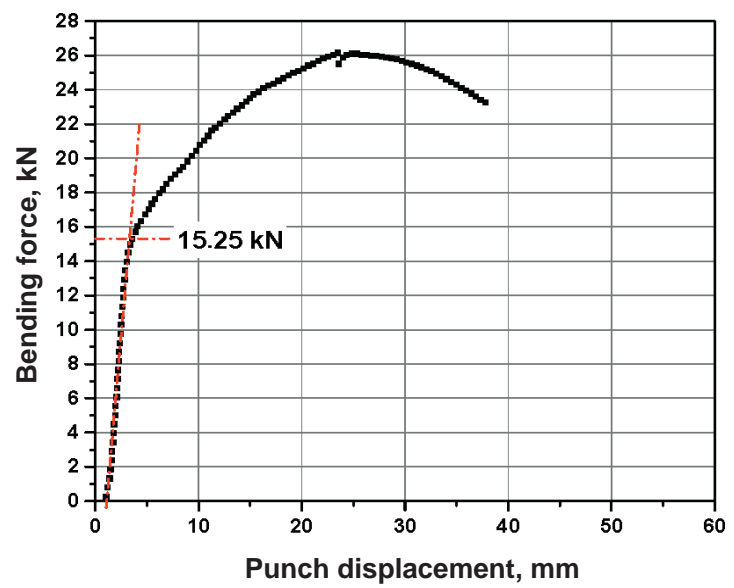

b)

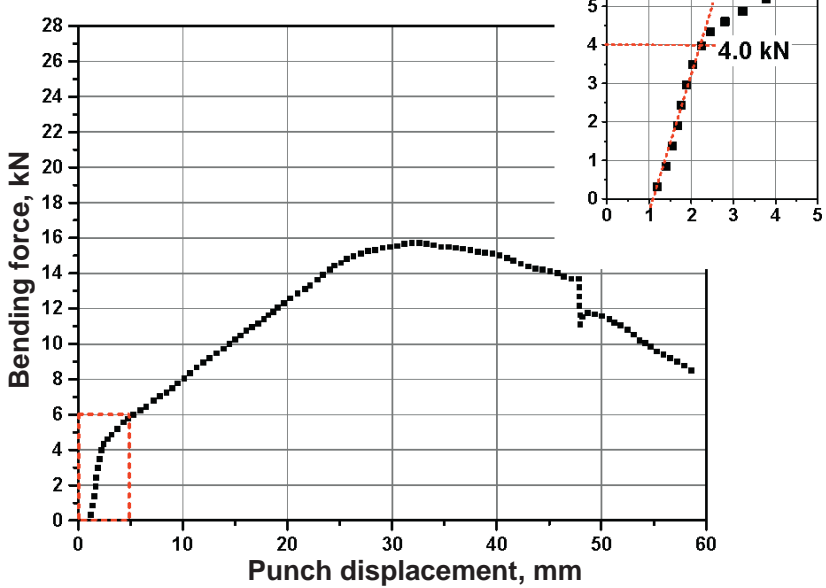

Fig. 3. Bending force as a function of punch displacement. Material P1; a) after softening $690^{\circ} \mathrm{C} / 4 \mathrm{hours}\left(\boldsymbol{R}_{\mathrm{p} / \mathrm{zg}}=1350 \mathrm{MPa}\right)$, b $)$ after austenitising $950^{\circ} \mathrm{C} / 30 \mathrm{~min}$ and regulated cooling up to $300^{\circ} \mathrm{C}\left(\boldsymbol{R}_{\mathrm{p} / \mathrm{zg}}=354 \mathrm{MPa}\right)$

Rys. 3. Siła zginania w funkcji przemieszczenia stempla. Materiał P1; a $)$ po zmiękczaniu $690^{\circ} \mathrm{C} / 4$ godziny $\left(R_{\mathrm{p} / \mathrm{zg}}=1350 \mathrm{MPa}\right)$, b) po austenityzowaniu $950^{\circ} \mathrm{C} / 30 \mathrm{~min}$. i regulowanym chłodzeniu do $300^{\circ} \mathrm{C}\left(\boldsymbol{R}_{\mathrm{p} / \mathrm{zg}}=354 \mathrm{MPa}\right)$

\subsection{FIRING TEST RESULTS FOR PERFORATED PANELS}

For heat treatment variants optimised to achieve the highest ballistic protection, perforated sheet samples were manufactured for firing tests. The P2 heat was used to produce two $9 \times 300 \times 300 \mathrm{~mm}$ sheets, for which different triangular perforation systems R5.6T10 and R5.7T8 were used, where $R$ - a hole diameter and $T$ - distance between the centres of the adjacent holes. The sheet was perforated in the softened state by laser cutting, and then it was subjected to final heat treatment using isothermal annealing at $215^{\circ} \mathrm{C}$ for 96 hours. The test system in the firing tests consisted of a perforated panel and a $2 \mathrm{~mm}$ thick aluminium whitness plate located behind it at a distance of $50 \mathrm{~mm}$. The firing was carried out at an angle of $30^{\circ}$ according to the NATO procedure, using ammunition cal. $7.62 \times 39 \mathrm{~mm}$ API BZ. The firing tests were carried out at the testing station at Wojskowy Instytut Techniki Pancernej i Samochodowej in Sulejówek.

The test results for the R5.6T10 perforation are presented in Table 5 and Fig. 4. The result of the test was an assessment of the effects of perforating the whitness plate, in terms of the size and extent of the hole, which indicate the absorbed energy and the degree of destruction of the projectile core on the perforated plate. It was shown that the best variant was the R5.6T10 perforation system panel, for which high edge effect efficiency was observed (Fig. 4b). The weight reduction for this solution in relation to the solid panel is about $30 \%$.

For the panel with the R5.7T8 perforation system, the distance between the centres of the adjacent holes ( $\mathrm{T}$ ) was too small, which resulted in fragments of the material getting knocked out, as a result of which a small part of the projectile energy was absorbed. a)

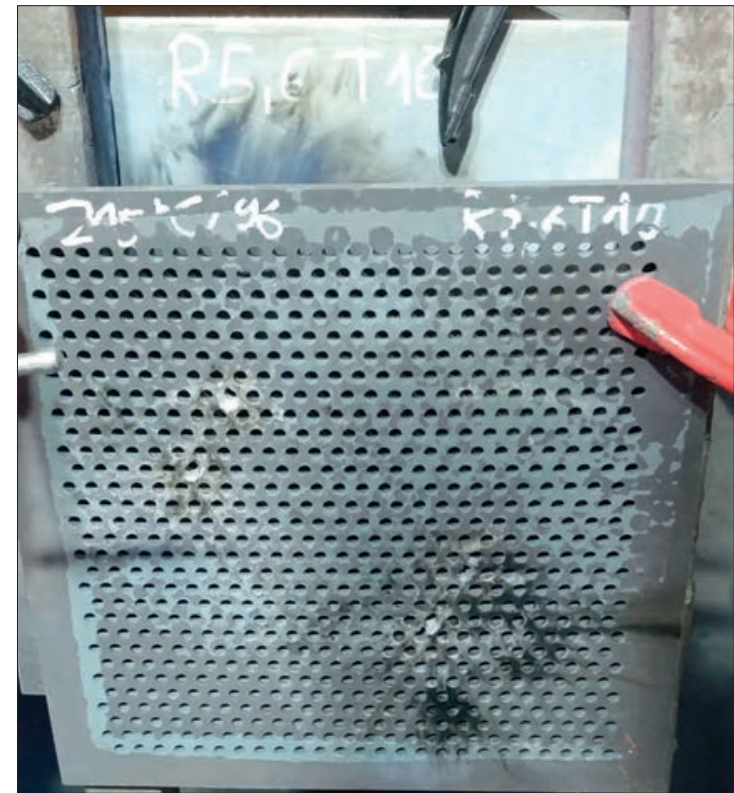

b)

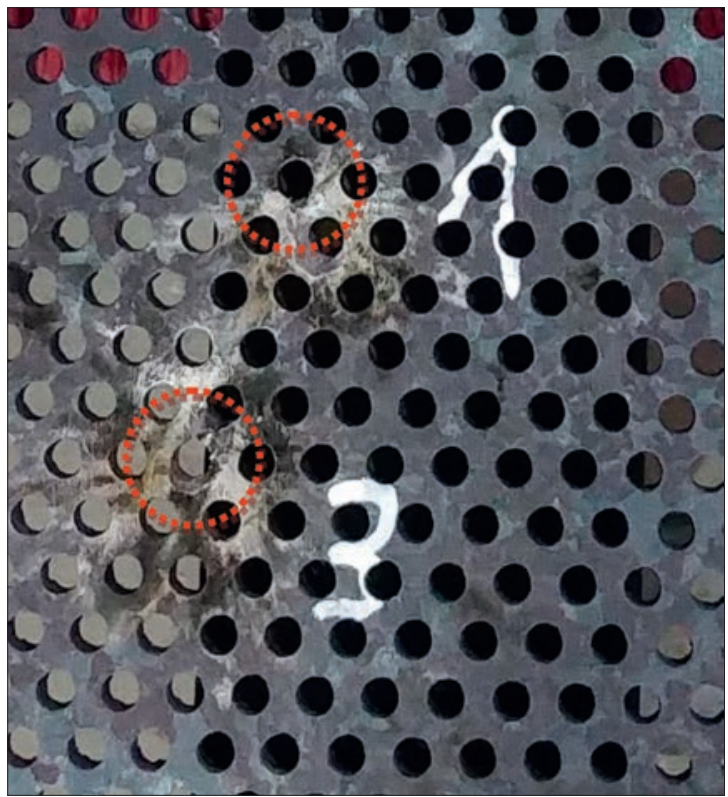

Fig. 4. Photograph of the R5.6T10 perforated panel after firing and the sites of impact of the projectile core on the perforated panel Rys. 4. Fotografia płyty perforowanej R5,6T10 po ostrzale oraz miejsca uderzenia rdzenia pocisku w płytę perforowaną 
Table 5. Firing test results for systems containing perforated sheets made of bainitic nanostructured steel - P2 heat, variant 215.96 , R5.6T10 (approx. 30\% clearance)

Tabela 5. Wyniki testów ostrzałem układów zawierających blachy perforowane ze stali nanostrukturalnej bainitycznej - wytop P2, wariant 215.96, R5,6T10 (prześwit ok. 30\%)

\begin{tabular}{|c|c|c|c|c|}
\hline No. & Material & Ammunition type / firing angle & Impact velocity [m/s] & \multicolumn{1}{|c|}{ Test result } \\
\hline 1 & P2.215.96 & \multirow{4}{*}{$7.62 \times 39 \mathrm{~mm} \mathrm{BZ} / 30^{\circ}$} & 712.0 & Slight puncture of the whitness plate \\
\hline 2 & $\mathrm{P} 2.215 .96$ & 716.1 & Puncture of the whitness plate \\
\hline 3 & $\mathrm{P} 2.215 .96$ & & 707.5 & No puncture of the whitness plate \\
\hline 4 & $\mathrm{P} 2.215 .96$ & & 701.3 & Puncture of the whitness plate \\
\hline
\end{tabular}

\section{SUMMARY}

The article presents the results of analyses regarding the material qualification for applications in ballistic protection constructions, based on the results of laboratory tests, selected aspects of manufacturing and processing technology as well as construction and material solutions in armour systems. The tested material was nanobainitic steel in two subgrades, with different values of mechanical properties, obtained using appropriately heat treatment parameters.

As regards qualification tests, preliminary tests of dynamic penetration resistance were undertaken using a Gleeble simulator. The methodology for testing dynamic indentation resistance was developed and the simulator equipment necessary for testing, not included in its standard equipment, was produced. A series of measurement of the dynamic resistance of indenting nanobainitic steel in the softened state and after the final heat treatment was made. These tests will be continued using a diversified structural state of the material and hardness in order to broaden the scope of measurement.

In the next area of research, a temperature range from approx. 650 to $250^{\circ} \mathrm{C}$, achieved as a result of cooling from $950^{\circ} \mathrm{C}$, suitable for deformation at very low stress levels and high material shaping ability was determined. In this temperature range, due to low hardness, there is e.g. the possibility of perforating using the punching method. The research in this scope will be continued.

The test results of firing perforated panels with perforation geometry type R5.6T10 made of nanobainitic steel P2.215.96 clearly showed the beneficial effect of the perforation, mainly due to the occurrence of the edge effect. The weight reduction for this solution in relation to the solid panel is about $30 \%$.
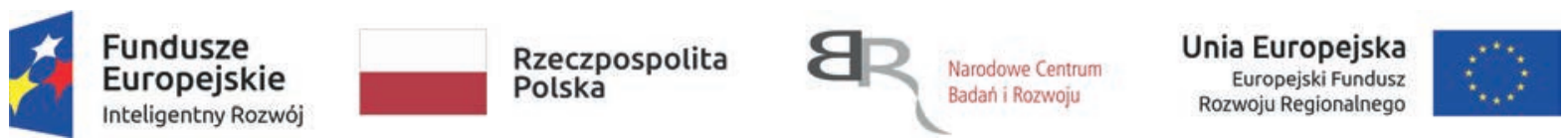

The article contains the results of research carried out under the project financed from structural funds POIR 4.1.4.00-0047/16: Development of the technology for the production of a lightweight observation and defence container (LOOK) made of ultra-high strength nanostructured steels.

\section{REFERENCES}

[1] Final report - Research Fund for Coal and Steel - European Commission, RFSR-CT-2012-00017. Understanding basic mechanism to optimize and predict in service properties of nanobainitic steels (MECBAIN). EUR $28463 \mathrm{EN}, 2017$.

[2] Y.T. Tsai, Y.W. Chen, J.R. Yang. Severe deformation of nanostructured bainitic steel. Procedia Engineering, 2017, 207, p. 1862-1867.

[3] L. Morales-Rivas, C. Garcia-Mateo, T. Sourmail, M. Kuntz, R. Rementeria, F.G. Caballero. Ductility of Nanostructured Bainite. Met als 2016, 6 (12), p. 302. doi:10.3390/met6120302.

[4] T. Sourmail, C. Garcia-Mateo, F.G. Caballero, L. Morales-Rivas, R. Rementeria, M. Kuntz. Tensile Ductility of Nanostructured Bainitic Steels: Influence of Retained Austenite Stability. Metals, 2017, 7 (1), p. 31. doi:10.3390/met7010031.

[5] L. Morales Rivas. Microstructure and mechanical response of nanostructured bainitic steels. PhD Thesis. National Center for Metallurgical Research (CENIM-CSIC), Spain, 2016.

[6] L. Morales-Rivas, C. Garcia-Mateo, M. Kuntz, T. Sourmail, F.G. Caballero. Induced martensitic transformation during tensile test in nanostructured bainitic steels. Mater. Sci. Eng., 2016, A, 662, p. 169-177.

[7] F. Hu, K.M. Wu, P.D. Hodgson. Effect of retained austenite on wear resistance of nanostructured dual phase steels. Mater. Sci. Tech., 2016, 32 (1), p. 40-48.

[8] J. Marcisz, B. Walnik, J. Gazdowicz. Dostosowanie technologicznych $i$ aplikacyjnych wtaściwości wysokowytrzymatych stali do wzrastajacych wymagań przemystu obronnego. IMŻ Report No. So-0950, 2017.

[9] B. Garbarz, W. Zalecki, B. Walnik, A. Wrożyna, P. Skupień. Opracowanie metody regulowania sktadu fazowego ultrawytrzymatych stali nanostrukturalnych w celu uzyskania wytrzymatości i ciagliwości dostosowanych do różnych warunków eksploatacji. IMŻ Report No. So-0925, 2016.

[10] J. Marcisz, B. Garbarz, B. Walnik, H. Krztoń, Z. Kania-Pifczyk. Correlation of mechanical properties and resistance to perforation of armour elements made of nanostructured bainitic steel. IMŻ Report No. So-0970 Part 1, 2018, Part 2-2019.

[11] X.Z. Qinghui, Q. Kun, S. Li. A technique for hi-speed indentation experiment based on Hopkinson bar. Procedia Engineering, 2017, 173, p. 601-607.

[12] J. Kolenda, L. Kyzioł. Porównawcza miara dynamicznej twardości metali. Scientific Journal of Polish Naval Academy, 2007, Year XLVIII, (3), p. 170.

[13] G. Subhash, B.J. Koeppel, A. Chandra. Dynamic Indentation Hardness and Rate Sensitivity in Metals. J. Eng. Mater. Technol. 1999, 121 (3), p. 257-263.

[14] K.E. Thelning. Steel and its Heat Treatment. Butterworths, 1975.

[15] Polish Committee for Standardisation. PN-EN ISO 14577-1:201509. Metallic materials - Instrumented indentation test for hardness and materials parameters - Part 1: Test method. Warszawa: PKN, 2015.

[16] Polish Committee for Standardisation. PN-EN ISO 6507-1:201805. Metallic materials - Vickers hardness test-Part 1: Test method. Warszawa: PKN, 2018.

[17] Polish Committee for Standardisation. PN-EN ISO 6506-1: 201412. Metallic materials - Brinell hardness test - Part 1: Test method. Warszawa: PKN, 2014.

[18] G. Subhash, B.J. Koeppel, A. Chandra. Dynamic indentation hardness and rate sensitivity in metals. Journal of Engineering Materials and Technology, Transactions of the ASME, 1999, 121, p. 257263.

[19] A.H. Almasri, G.Z. Voyiadjis. Effect of Strain Rate on the Dynamic Hardness in Metals. Journal of Engineering Materials and Technology, 2007, 129, p. 505-512.

[20]D. Tabor. A simple theory of static and dynamic hardness. Proc. Roy. Society Series A, 1947, p. 247-274.

[21] M.N. Bassim, A.G. Odeshi. Shear strain localisation and fracture in high strength structural materials. Archives of Materials Science and Engineering, 2008, 31, (2), p. 69-74. 